\title{
SEBUAH INFORMASI MUTAKHIR HASIL PENELITIAN TAHUN 2013 DI SITUS KEDATON PLERET, KABUPATEN BANTUL, D.I. YOGYAKARTA
}

\section{RECENT INFORMATION FROM 2013 RESEARCH ON KEDATON PLERET SITE, BANTUL REGION, D.I.YOGYAKARTA}

\author{
Henki Riko P \& Hery Priswanto \\ Balai Arkeologi Yogyakarta \\ henkiriko@gmail.com \\ priswanto.balaryk@gmail.com
}

\begin{abstract}
Pleret is one sites that has the Islamic Mataram long way in archaeological research. Pleret existence can not be ignored in a civilization of the Islamic Mataram Period, which also has a parallel position with Kutagede, Kerto, Kartosuro, Surakarta and Yogyakarta. But the glory of pleret was not able to be seen as a whole, only a few partsthat can be met partially. The purpose of writing this article is one of the publications of the result of the research efforts that have been conducted Pleret Kedaton site by displaying the latest findings in the form of the remains of building that are considered part of the building Cepuri keben / ward Srimanganti
\end{abstract}

Keywords: Kedaton, Islamic Mataram, Publications, Srimanganti

\begin{abstract}
ABSTRAK
Pleret adalah salah situs Perkotaan Masa Mataram Islam mengalami perjalanan panjang dalam kegiatan penelitian arkeologi. Keberadaan Pleret tidak bisa diabaikan dalam peradaban Masa Mataram Islam, yang mana juga mempunyai kedudukan sejajar dengan Kutagede, Kerto, Kartosuro, Surakarta dan Yogyakarta. Namun sisa-sisa kejayaan Pleret sudah tidak disaksikan secara utuh, hanya beberapa bagian secara parsial dapat ditemukan. Tujuan penulisan artikel ini adalah salah upaya publikasi hasil penelitian yang telah dilakukan Situs Kedaton- Pleret dengan nemampilkan temuan terbaru berupa sisa-sisa bangunan yang diduga bagian dari cepuri bangunan keben/ bangsal srimanganti
\end{abstract}

Kata Kunci: Kedaton, Mataram Islam, Publikasi, Srimanganti

Tanggal masuk : 22 September 2013

Tanggal diterima : 24 November 2013 


\section{PENDAHULUAN}

Nama "Pleret" sudah tidak asing lagi bagi dunia arkeologi di Indonesia, Pleret merupakan bekas ibukota Kerajaan Mataram Islam pada masa kepemimpinan Sultan Amangkurat I, yang berkuasa pada 1646 - 1677 TU. Sisa-sisa Kraton Pleret dapat diketahui dari beberapa tinggalan arkeologi serta toponim yang tersebar di wilayah Kecamatan Pleret. Penelitian arkeologi yang telah dilakukan sejak tahun 1976 2012 oleh berbagai instansi menghasilkan gambaran sementara mengenai Kraton Pleret, diantaranya:

1. Benteng Kraton Pleret berbentuk jajaran genjang dengan sudut kemiringan $12^{\circ}$, tersusun dari bahan bata, batu putih, dan andesit, lebar benteng bagian dasar/tubuh berkisar $220-280 \mathrm{~cm}$. Sisa benteng yang dapat terlacak hanya sisi barat, selatan dan timur, sementara sisi utara tidak ditemukan reruntuhannya (Alifah dan Priswanto 2012, 190).

2. Masjid Kauman Pleret yang terletak di Dusun Kauman, tersisa beberapa komponen yaitu bagian mihrab, umpak berjumlah 22 buah, pagar benteng masjid, dan beberapa struktur pondasi bangunan inti masjid. Di sebelah barat Masjid Kauman terdapat kompleks makam Ratu Labuhan yang merupakan istri dari Amangkurat I (Priswanto dan Alifah 2011, 122).

3. Kompleks Makam Ratu Malang (istri Amangkurat I) yang terletak di atas bukit bernama Gunung Kelir. Makam ini terdiri dari 28 nisan, yang dikelompokkan menjadi 3 lokasi, yaitu: 19 nisan berada di halaman depan, 1 nisan di halaman belakang (nisan Dalang Panjang Mas), dan 8 nisan berada di halaman inti (salah satunya nisan dari Ratu Malang).
4. Kegiatan ekskavasi rutin yang dilakukan oleh Dinas Kebudayaan Provinsi DIY pada 2008 - 2012 di sekitar Desa Pleret menghasilkan temuan sisa-sisa pondasi struktur bangunan, berupa benteng, pagar, lantai, saluran air, bekas umpak, dan komponen jalan (Tim Penelitian, 2008, 2009, 2010, 2011, 2012).

5. Kraton Pleret dikelilingi oleh bangunan-bangunan air yang mendukung pemukiman Kraton dan masyarakat sekitarnya. Hal ini didukung oleh adanya toponim Segarayasa (Segara: laut, yasa: membuat), disebutkan pula dalam babad momana dan babad ing sangkala (Adrisijanti 2000, 72).

Selain dari hasil ekskavasi maupun survei permukaan, terdapat pula toponim di Kecamatan Pleret yang menunjukkan keberadaan sebuah kerajaan pada masa lalu. Toponim tersebut yaitu Kauman, Gerjen, Trayeman, Panegaran, Kepanjen, Bintaran, Surodinanggan, Jaha, Semarangan, Kunden, Demangan, Mertosanan, Pugeran, Suren, Kanoman, Kaputren, Kedaton, Kentolan, Wirakerten, dan Sampangan (Adrisijanti 2000, 281). Toponim menunjukkan pembagian wilayah/pengelompokan hunian, sesuai dengan pekerjaannya maupun keahliannya. Toponim Kauman digunakan sebagai pemukiman para ulama, Gerjen yaitu pemukiman para gerji (penjahit), Semarangan berarti tempat tinggal orang-orang dari Semarang.

Selain data arkeologi yang telah ditemukan, masih terdapat data historis berupa sumber pustaka yang berasal dari catatan-catatan perjalanan VOC, Babad Momana, Babad Ing Sangkala, dan Babad Tanah Jawi. Menurut sumber pustaka diatas, kraton Pleret mengalami kehancuran ketika terjadi penyerangan yang dilakukan oleh Trunojoyo, seorang 
bangsawan asal Madura. Sultan Amangkurat I berhasil melarikan diri hingga ke Tegal, namun akhirnya meninggal di daerah tersebut dan memperoleh gelar Pangeran Tegalwangi. Sebelum meninggal beliau mengangkat Pangeran Adipati Anom atau Mas Rahmat sebagai penggantinya dengan gelar Sunan Amangkurat II. Setelah Trunajaya meninggalkan Pleret menuju Kediri, maka Pangeran Puger menguasai kembali istana dan mengangkat dirinya menjadi Raja di Pleret dengan gelar Susuhanan ing Alaga (Adrisijanti 2000, 65). Sementara itu Amangkurat II mendirikan Kedaton baru di
Wanakarta/Kartasura dan mulai tinggal pada tahun 1680 TU (Adrisijanti 2000, 83). Kraton Pleret mulai ditinggalkan dan tidak digunakan sebagai ibukota Kerajaan lagi. Pada masa Perang Diponegoro (1825 - 1930) sisa-sisa Kraton Pleret digunakan kembali sebagai benteng pertahanan pasukan Pangeran Diponegoro melawan Belanda. Setelah berhasil memadamkan pemberontakan, Belanda memulai praktik kolonialismenya dengan membangun Pabrik Gula Kedaton di Desa Pleret. Proses pembangunan pabrik tersebut menggunakan sisa-sisa bata dari Kraton Pleret.

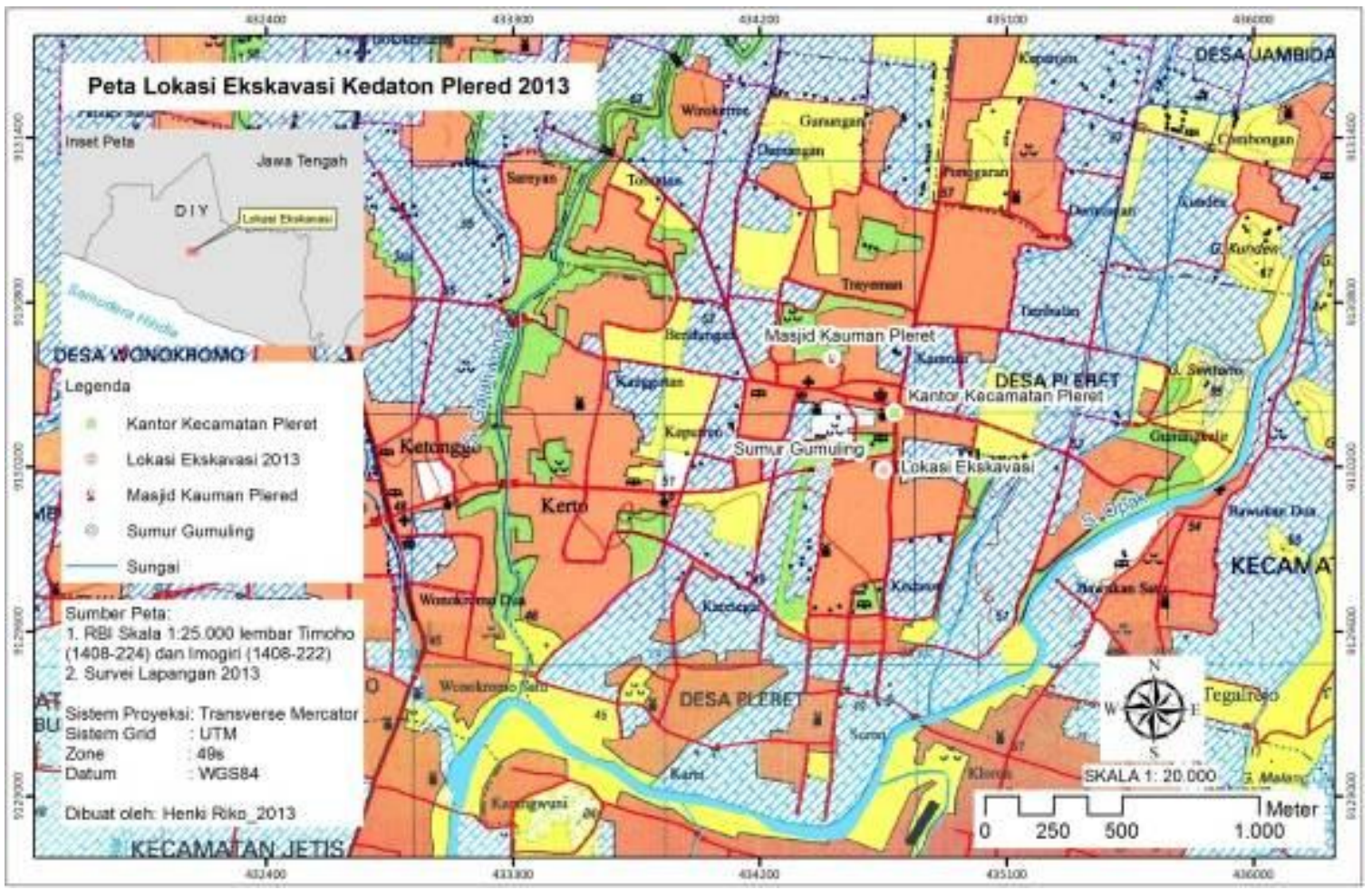

Peta 1. Lokasi Penggalian Situs Kedaton Desa Pleret.

(Sumber: Laporan Ekskavasi Situs Kedaton Tahap VI)

Pengunaan lahan saat ini yang berkembang dengan pesat turut berperan dalam hilangnya bekas Kraton Pleret. Selain itu, pembangunan perkantoran, fasilitas umum, dan pertokoan juga berdampak pada kerusakan sisa Kraton Pleret. Apabila hal tersebut diabaikan dan tidak diperhatikan maka beberapa data sejarah, data arkeologi maupun aspek lingkungan mengenai keberadaan Kraton Pleret diperkirakan akan lenyap. Oleh karena itu, dianjurkan untuk segera melakukan kegiatan penelitian arkeologi berupa kegiatan ekskavasi. Menindaklanjuti rekomendasi tersebut maka pada 
tanggal 1 April - 28 Mei 2013 dilakukan kegiatan ekskavasi Situs Kedaton Tahap VI yang berada di Blok I' dan II' pada peta master grid KCB Pleret yang berlokasi di Dusun Kedaton, Desa Pleret.

Hasil penelitian yang telah dilakukan oleh beberapa instansi belum menghasilkan temuan yang bersifat monumental untuk di tunjukkan kepada masyarakat umum. Penelitian terdahulu hanya dilakukan secara parsial dan berpindah-pindah di beberapa lokasi sekitar Desa Pleret sehingga hasil temuan belum dapat ditampakkan dan cenderung untuk di timbun kembali. Pada penelitian tahun ini, tim yang dibentuk oleh Dinas Kebudayaan Daerah Istimewa Yogyakarta berhasil menemukan sisa-sisa pondasi bangunan yang diperkirakan bagian dari Kedaton Pleret sehingga proses penggalian dipusatkan pada blok l' sisi barat. Temuan tersebut dirasa sangat potensial untuk ditindaklanjuti dan dipublikasikan kepada masyarakat umum sehingga pada kesempatan kali ini kami berusaha untuk menginformasikannya.

\section{HASIL KEGIATAN PENELITIAN SITUS KEDATON TAHAP VI (TAHUN 2013)}

\begin{abstract}
Kegiatan penelitian di Situs Kedaton di KCB Pleret telah dilaksanakan hampir empat dasawarsa yang di awali pada tahun 1976 hingga tahun 2012 oleh berbagai instansi. Penelitian difokuskan di Situs Kedaton untuk memperoleh sisa-sisa bangunan Keraton Pleret yang pernah eksis pada abad XVII Masehi. Hasil penelitian dilaksanakan oleh Dinas Kebudayaan Provinsi Daerah Istimewa Yogyakarta di Situs Kedaton Tahap V tahun 2012. Penelitian pada tahapan ini berhasil mengungkap sisa-sisa Keraton Pleret berupa indikasi pondasi tembok pagar Bangsal Srimanganti berdasarkan pada peta Rouffer dari Perancis. Hasil penelitian tahun 2013 yang memasuki pada tahapan VI juga memperoleh hasil yang sangat signifikan dan berkorelasi dengan data arkeologi hasil penelitian terdahulu.
\end{abstract}

Kegiatan ekskavasi di Situs Kedaton, Pleret tahap VI pada tahun 2013 ini telah membuka kotak ekskavasi sebanyak 28 kotak (lihat Tabel 1). Kotakkotak ekskavasi tersebut berada pada Blok I' dan II', lokasi ekskavasi terkonsentrasi pada lahan milik Bapak Prasetyo serta lbu Sri Hardiningsih warga Kedaton, Pleret, Bantul.

Tabel 1. Rekapitulasi Pembukaan Kotak Ekskavasi Situs Kedaton Tahap VI

\begin{tabular}{|c|c|c|}
\hline No & Sektor & Nama Kotak \\
\hline 1 & l' & I'r 250 \\
\hline 2 & $I^{\prime}$ & l's 242 \\
\hline 3 & l' & l's 247 \\
\hline 4 & I' & I'u 244 \\
\hline 5 & l' & l'u 245 \\
\hline 6 & I' & l'u 247 \\
\hline 7 & I' & l'u 250 \\
\hline 8 & I' & I'u 251 \\
\hline 9 & $\mathrm{I}^{\prime}$ & I'v 244 \\
\hline 10 & I' & I'v 245 \\
\hline 11 & I' & I'v 246 \\
\hline 12 & I' & I'v 247 \\
\hline 13 & I' & I'v 248 \\
\hline 14 & I' & l'v 249 \\
\hline 15 & I' & I'v 250 \\
\hline 16 & I' & I'v 251 \\
\hline
\end{tabular}

\begin{tabular}{|c|c|c|}
\hline No & Sektor & Nama Kotak \\
\hline 17 & I' & I'w 240 \\
\hline 18 & I' & I'w 245 \\
\hline 19 & I' & I'w 246 \\
\hline 20 & I' & I'W 247 \\
\hline 21 & I' & I'W 248 \\
\hline 22 & I' & I'W 249 \\
\hline 23 & I' & I'x245 \\
\hline 24 & I' & I'x 246 \\
\hline 25 & I' & I'y 245 \\
\hline 26 & I' & I'y 246 \\
\hline 27 & I' & II'a 246 \\
\hline 28 & II' & II'a 247 \\
\hline
\end{tabular}

(Sumber: Laporan Ekskavasi Situs Kedaton Tahap VI) 
Selain kegiatan ekskavasi, dalam rangka mengungkap Situs Kedaton secara faktual juga dilakukan penelusuran data sekunder berupa referensi yang berkaitan dengan Situs Kedaton secara khusus maupun KCB Pleret secara lebih luas. Penelusuran referensi tersebut berhasil memperoleh data berupa peta-peta kuna dari berbagai sumber seperti KITLV, dan Dinas Kebudayaan D.I. Yogyakarta. Salah satu peta yang berhasil ditelusuri dan diperoleh sebuah Peta Kuno buatan Rouffaer, tanpa tahun.

Peta ini masih dalam tahap klarifikasi ulang karena belum diketahui keaslian sumbernya. Peta diperoleh dari Dinas Kebudayaan Daerah Istimewa Yogyakarta, dan merupakan sketsa Kraton Pleret dan diperkirakan buatan Rouffaer tahun 1889 berskala 1:10.000. Seperti terlihat di bawah ini, peta berisikan bagian-bagian Kraton Pleret beserta nama toponim desa yang sampai sekarang masih dapat dilacak.

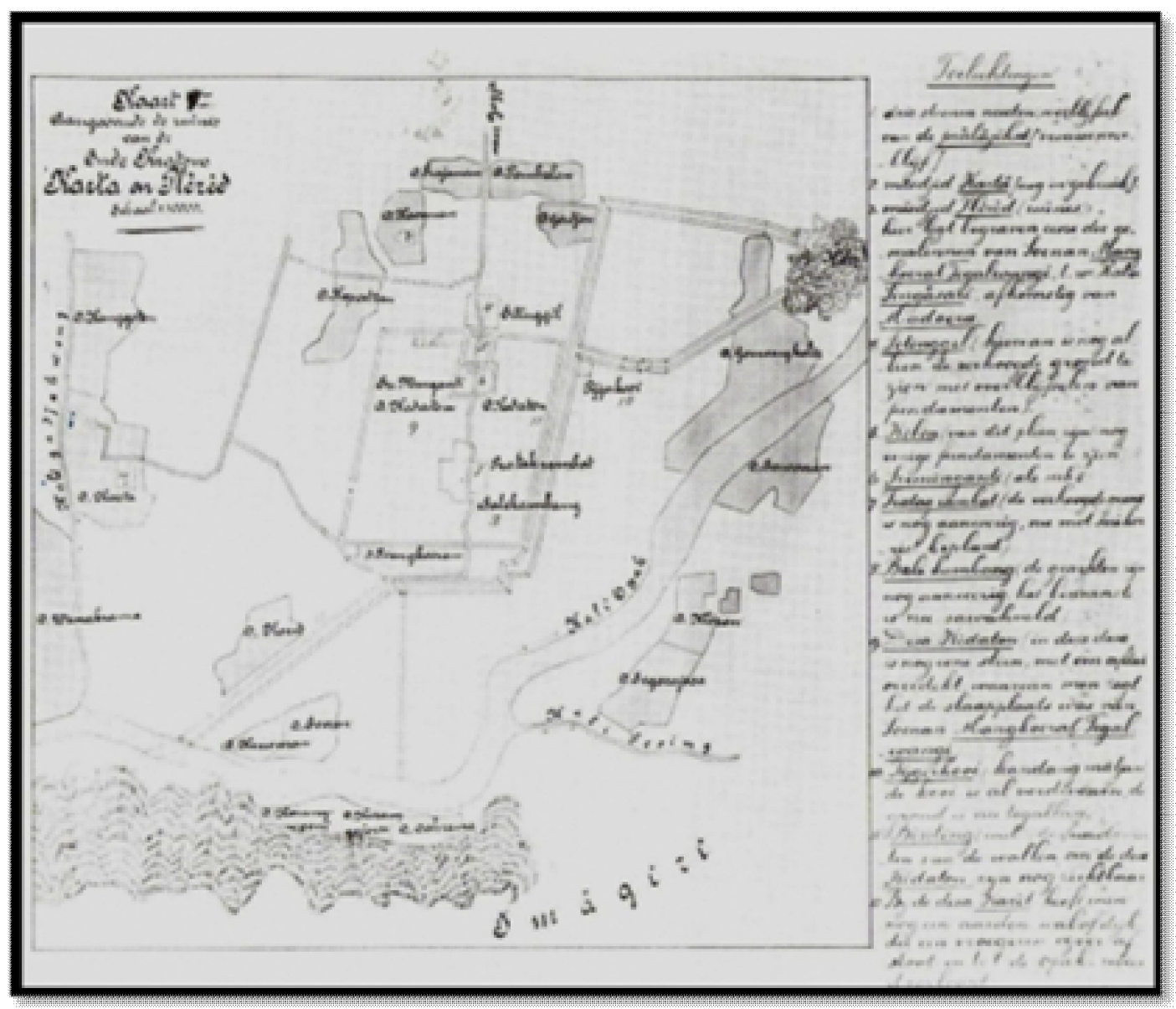

Peta 2. Peta Kuno Kraton Pleret yang Diperkirakan Buatan Rouffaer, tanpa tahun. (Sumber: Dinas Kebudayaan DIY).

Bagian dari Kraton Pleret yang dapat diidentifikasi dari peta di atas yaitu: Masjid Plered (Kauman), Sitiinggil, Keben, Srimanganti, Tratag rambat, Balekambang, Tiggerkort (Kandang Simo), Benteng, dan Parit (?). Selain itu, terdapat juga nama toponim yang berada di sekitar Kraton Pleret, yaitu: D (Desa).Trajeman, D. Tambalan, D.
Kaoeman, D. Gerdjen, D. Kapoetren, D. Kedaton, D. Goenoengkelir, Bawoeran, D. Kloran, D. Segarajasa, D. Kanggotan, D.Kerta, D. Wanakrama, D. Karet, D. Poengkoran, D. Suren, D. Kanoman, D. Karanggayam, D. Karangwuni, dan D. Dahrono. Namanama toponim diatas masih digunakan hingga saat ini, dan memiliki latar 
belakang penamaan masing-masing. Contohnya D. Gerjen merupakan permukiman para gerji (penjahit), $D$. Kaoeman merupakan permukiman para alim ulama, dan D. Suren yaitu permukiman para abdi dalem penyisir (Adrisijanti 2000, 79) .

\section{RAGAM DAN KARAKTER DATA ARKEOLOGI SITUS KEDATON}

\section{Data Artefaktual}

Temuan artefaktual pada tahun 2009, 2012, dan 2013 bervariasi antara lain gerabah, keramik, logam, tulang, dan kaca. Hasil rekapitulasi temuan-temuan

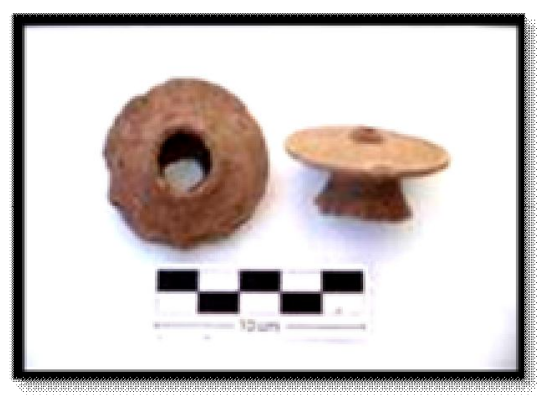

Foto 1. Fragmen kendi kotak I' I 231 - tahun 2009 (Dok. Tim Penelitian tahun 2009) artefak tersebut di atas menunjukkan bahwa gerabah merupakan temuan artefaktual yang paling banyak. Temuan logam, tulang, dan kaca ditemukan pada tanah yang telah teraduk atau disturbed yang diduga berasal dari kegiatan manusia pada saat ini, seperti lahan yang dipakai sebagai tempat pembuangan sampah. Hal ini dibuktikan dengan ditemukannya sampah lain berupa kain bekas dan barang-barang berbahan plastik. Tulang dan kaca hanya ditemukan pada ekskavasi tahun 2009 pada tanah yang teraduk. Wadah gerabah yang diduga merupakan bagian dari kendi tahun 2009, juga ditemukan pada ekskavasi tahun 2012 dan 2013 dengan bentuk yang sama.

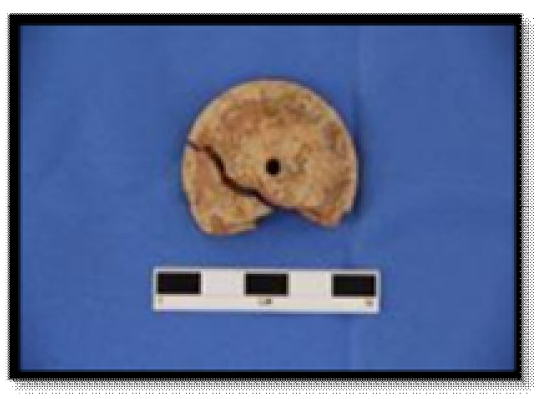

Foto 2. Fragmen kendi kotak I' n 221 - tahun 2012 (Dok. Tim Penelitian tahun 2012)

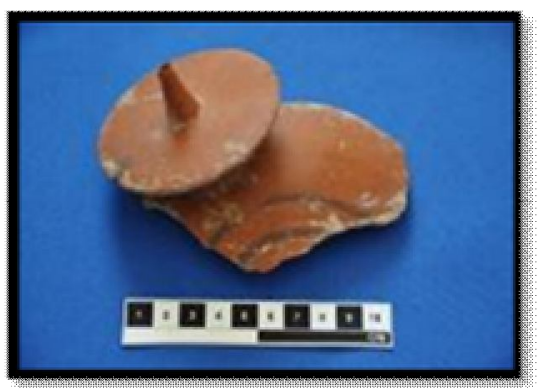

Foto 3. Fragmen kendi kotak I' y 245 - tahun 2013 (Dok. Tim Penelitian tahun 2013)

Tabel 2. Rekapitulasi Data Artefaktual Situs Kedaton Dari Hasil Penelitian Tahun 2009, 2012, dan 2013

\begin{tabular}{|c|c|c|c|c|c|}
\hline \multirow{2}{*}{ No. } & \multicolumn{5}{|c|}{ Temuan Artefaktual } \\
\cline { 2 - 6 } & Tahun & Gerabah & Keramik & Logam & Kaca \\
\hline 1 & 2009 & 252 & 15 & 1 & 0 \\
\hline 2 & 2012 & 157 & 60 & 4 & 0 \\
\hline 3 & 2013 & 179 & 5 & 2 & 2 \\
\hline \multicolumn{7}{r}{} & 588 & 80 & 7 & 2 \\
\hline
\end{tabular}

Sumber: Laporan Ekskavasi Situs Kedaton Tahap II, V, dan VI 
Berdasarkan hasil rekapitulasi data artefaktual dalam bentuk fragmentaris di Situs Kedaton diketahui bahwa sebanyak $86 \%$ atau 588 buah berupa data artefaktual berupa gerabah, menyusul 11 $\%$ atau 80 buah data artefaktual berupa keramik, berikutnya $1,03 \%$ atau 7 buah berupa fragmen logam, dan 0,29\% berupa fragmen kaca. Dominasi data artefaktual berbahan gerabah ini menunjukkan bahwa gerabah merupakan primadona sebagai piranti dalam menunjang kehidupan sehari-hari Kedaton Pleret masa lampau $\mathrm{Hal}$ ini dikarenakan dari daerah ini dan sekitarnya gerabah mudah dipeorleh dalam jumlah yang banyak. Beberapa fragmen gerabah yang dijumpai menunjukkan kualitas yang bagus berdasarkan bahan yang digunakan, serta hiasan pada bagian permukaannya. Bentuk alat-alat dari bahan tanah ini sebagian besar berupa wadah seperti kendi, pengaron, kendil, mangkuk dan cepuk. Penggunaan alatalat ini tentunya untuk mendukung berbagai keperluan dan kepentingan dalam kehidupan keseharian.

Selain gerabah, keramik juga digunakan sebagai piranti penunjang kehidupan sehari-hari. Berdasarkan kualitasnya keramik yang berasal Cina, Asia Tenggara Daratan dan Eropa memang lebih bagus dibanding dengan gerabah. Berdasarkan kuantitas dan kualitas data artefaktual berupa gerabah dan keramik yang ditemukan di Situs Kedaton tersebut diperoleh informasi bahwa Situs Kedaton merupakan sebuah situs permukiman dengan masyarakat pendukung berstrata menengah ke atas dengan struktur masyarakat yang tertata dan teratur. Sebagaimana diketahui Situs Kedaton merupakan situs pemukiman dan salah satu bekas pusat kerajaan Mataram Islam pada abad XVII-XVIII M.

\section{Data Arsitektural}

Data arsitektural yang diperoleh dari kegiatan ekskavasi Situs Kedaton tahap VI dengan membuka sebanyak 28 kotak ekskavasi, sebagian besar struktur yang ditemukan dalam kondisi tidak utuh lagi, yang tersisa hanya bagian fondasi atau dasar. Beberapa struktur yang masih dapat teridentifikasi yaitu sisa struktur tembok pagar bagian sudut sisi barat daya, dan dua sisa struktur bangunan, yaitu

- Struktur tembok pagar tersebut dijumpai di kotak l' v 246, l' s 247, I' u 247, l' v 247, I' w 247, l' v 249, l' v 250 , I' v 251, I' w 246, I' w 247, l' w 248, dan l' w 249. Indikasi sisa struktur tembok dengan ukuran lebar 2,60 meter terdiri dari 20 lapis bata secara vertikal. Struktur tembok pagar ini membentuk sebuah sudut yaitu sudut barat daya dengan orientasi utara-selatan dan timur-barat. Sisa struktur tembok berupa bagian pondasi atau kaki bangunan. Berdasarkan indikasi bentuk, ukuran, serta lokasi temuan, struktur tembok tersebut ini diduga bagian dari sebuah bangunan yang masif yaitu seperti tembok benteng atau cepuri. 


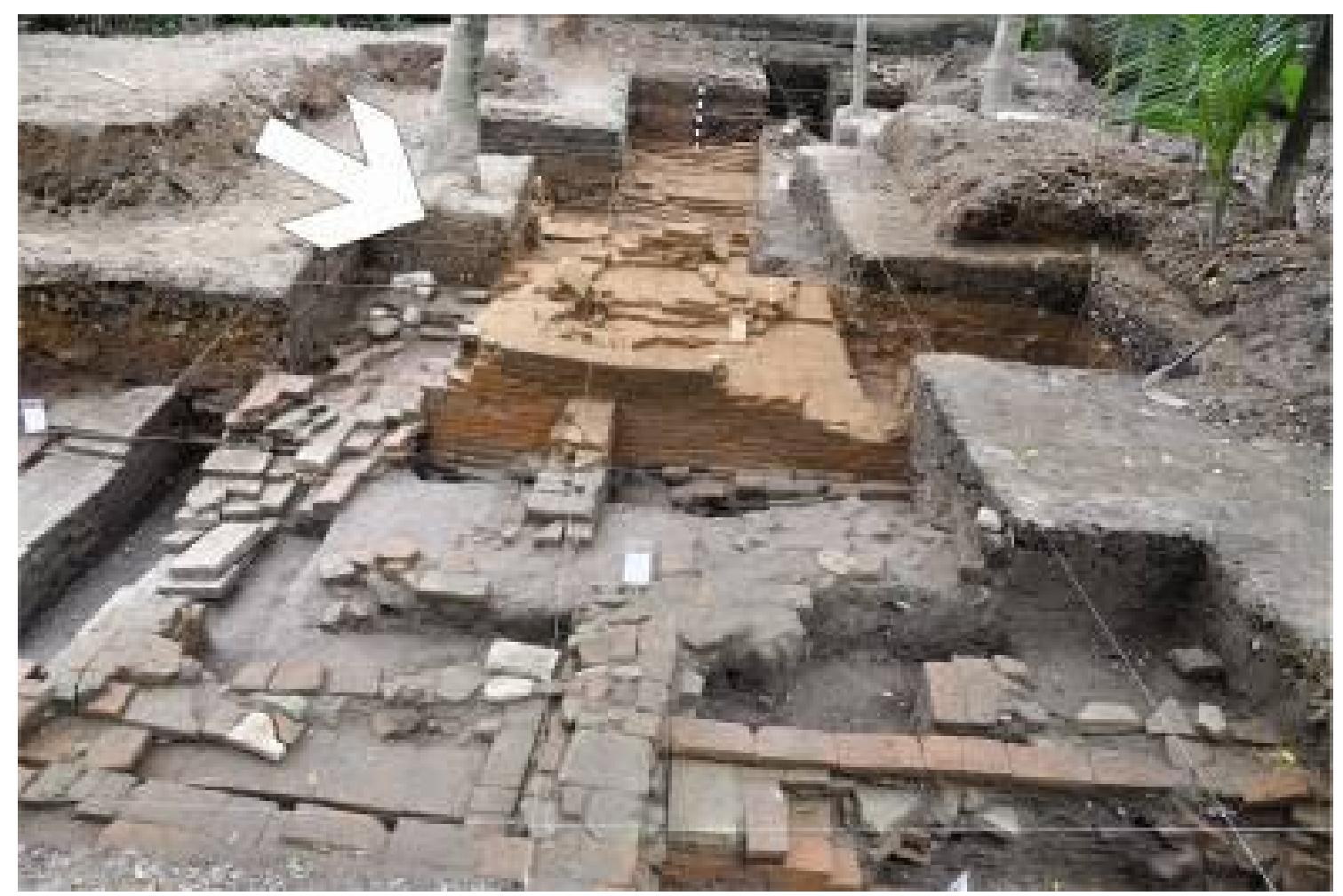

Foto 4. Detail Struktur bata yang diduga sisa cepuri bangsal Keben $(\rightarrow)$

(Dok. Tim Penelitian Tahun 2013)

Berdasarkan hasil ekskavasi diketahui bahwa lebar tembok cepuri yang mengelilingi kompleks Kraton Pleret mempunyai ukuran lebar sekitar $\pm 2,80$ meter, sedangkan ukuran lebar struktur tembok pagar sekitar $\pm 2,60$ meter juga merupakan sebuah satu kesatuan dari komponen bangunan cepuri. Merunut hasil ekskavasi Situs Kedaton tahun 2009 serta identifikasi beberapa peta kuna Pleret, struktur tembok pagar yang ditemukan tersebut diduga bagian dari sisa bangunan cepuri bangsal Keben atau Kemandungan.

Jika temuan struktur bata di lokasi ini identifikasikan merupakan Bangsal Keben atau Kemandungan Kraton Pleret, berdasarkan analogi struktur dan komponen kraton yang masih dapat dijumpai hingga sekarang adalah Kraton
Yogyakarta dan Surakarat. Mengacu pada Ensiklopedia Kraton Yogyakarta, definisi Bangsal Kemandungan terdiri dari Kemandungan Lor dan kemandungan selatan. Kemandungan Lor terletak di sisi utara kraton di antara siti hinggil utara dan srimanganti di masuki melalui Regol Brojonolo di utara dan Regol Srimanganti di selatan di tengahnya terdapat Bangsal Pancaniti. Sebatang pohon keben (barringtonia asiatica) yang tumbuh besar menaungi halaman ini sehingga Kemandungan Lor lebih dikenal dengan sebutan keben. Bangsal kemandungan pernah digunakan sebagai lokasi penyimpanan benda-benda upacara kerajaan (Dwiyanto 2009, 18). 


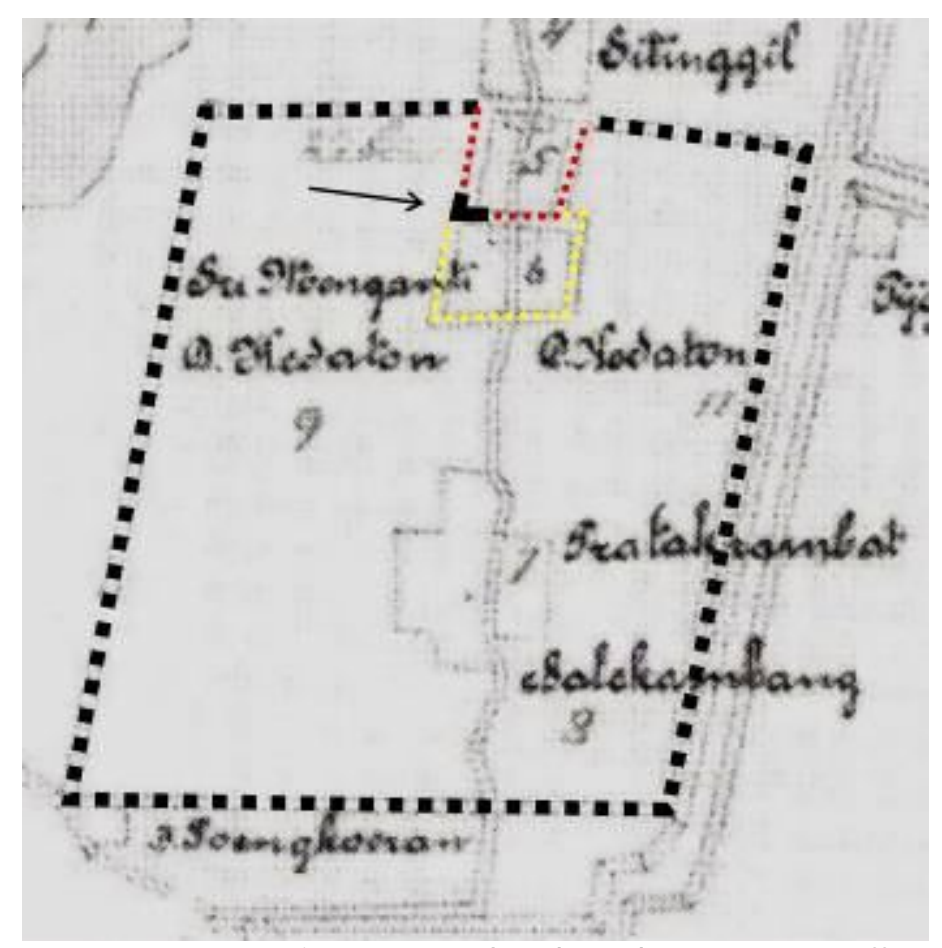

Peta 3. Interpretasi temuan struktur bata dengan peta Rouffer Cepuri Kraton Pleret (hitam); Cepuri Keben (merah); Cepuri Srimanganti (Kuning) (Sumber: Peta Rouffer, Tanpa Tahun)

Hasil penelitian Situs Kedaton tahun 2009 juga diperoleh data serupa yaitu struktur pondasi tipe I yang dijumpai di kotak I' n 248, I' m 248, dan I' n 250 yang mempunyai ukuran lebar \pm 2,60 meter. Hasil penelitian Situs Kedaton Tahun 2012 juga memperoleh data arsitektural yang diindikasikan sebagai sisa-sisa Keraton Pleret. Diantaranya temuan di kotak I' $\mathrm{n} 221$ dan I O-P 221 yang diindikasikan sebagai pondasi tembok pagar Bangsal Srimanganti berdasar pada Peta Rouffaer dari perancis tahun 1889. (Tim Penelitian tahun 2012, hlm. 149). Lokasi yang yang diindikasikan sebagai pondasi tembok pagar Bangsal Srimanganti dengan hasil ekskavasi tahun 2013 berada di sebelah selatan berjarak 200 meter.

- Bangunan I dijumpai pada kotak I'x 245, l' x 246, l' y 245, l' y 246, II' a 246, dan II' a 247 . Komponen bangunan I sebagian besar berupa struktur bata serta selajur struktur batu putih sebanyak 5 lapis yang berorientasi Utara-Selatan. Keberadaan struktur bata bangunan I berdasarkan Sketsa Kraton Pleret yang berasal dari perpustakaan Kraton Yogyakartadiduga merupakan lokasi Masjid Suranata atau Panepen. Lokasi struktur bangunan I tepat persis disebelah barat struktur tembok pagar yang diduga cepuri bangsal Keben berjarak 2 meter. 


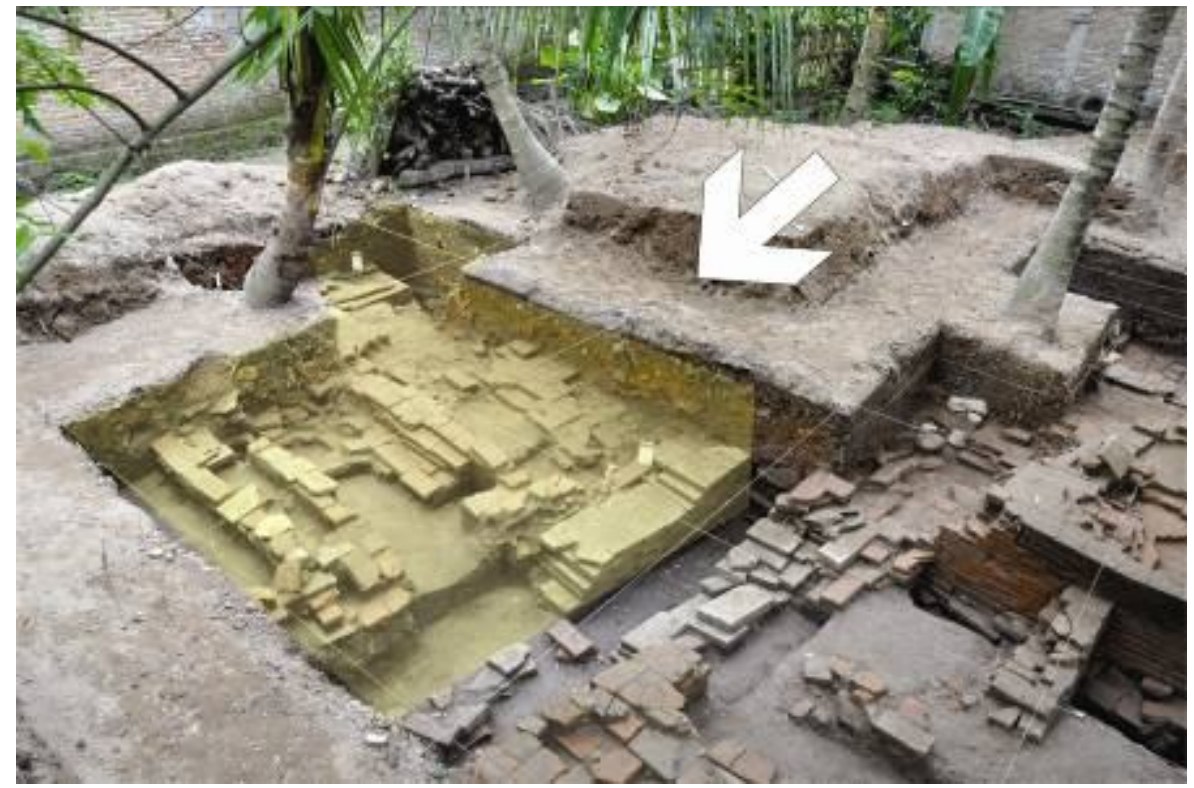

Foto 5. Detail struktur bata pada bangunan I $(\rightarrow)$

(Dok. Tim Penelitian Tahun 2013)

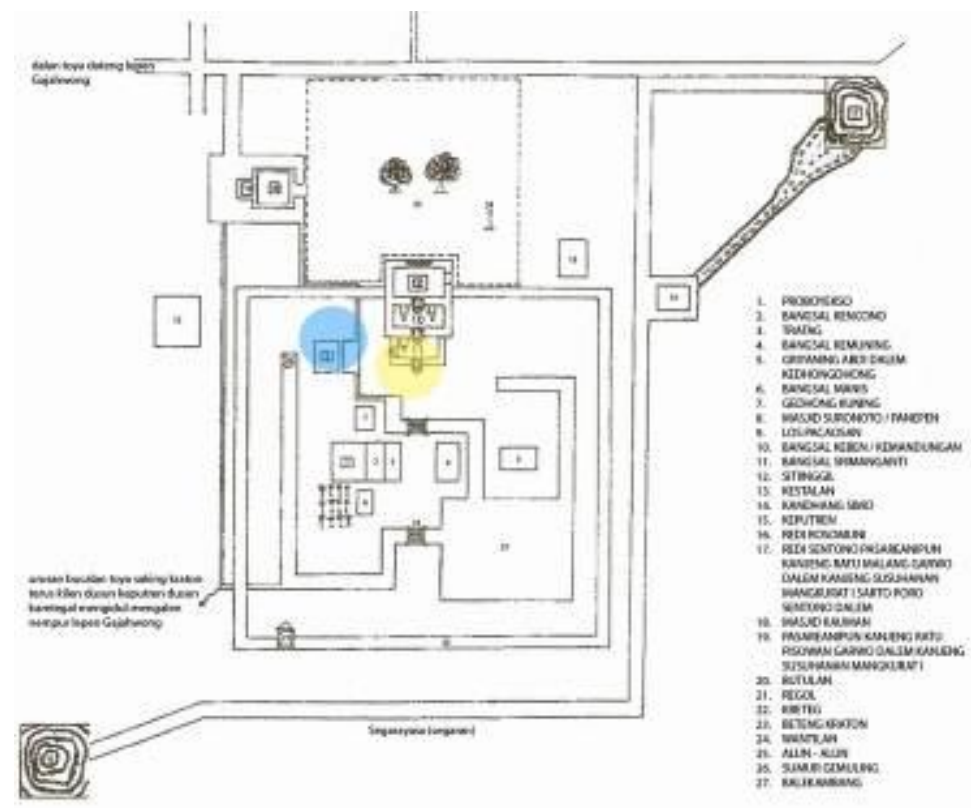

Gambar 1. Interpretasi lokasi bangunan I (lingkaran biru)

(Sumber: Sketsa Kraton Pleret yang berasal dari perpustakaan Kraton Yogyakarta)

- Bangunan II dijumpai di kotak l' u 244, I' u 245, l' v 244, l' v 245, l' v 246, l' w 245, dan I' w 246 . Bangunan II didominasi struktur bata berada di sebelah selatan struktur tembok pagar yang diduga bagian cepuri Keben. Mengacu pada Sketsa Kraton Pleret
Kuna yang berasal dari perpustakaan Kraton Yogyakarta, lokasi bangunan II ini berada di sebelah selatan bangsal Keben yaitu bangunan bangsal Srimanganti. Struktur-struktur bata pada bangunan II diduga merupakan sisa-sisa bangsal Srimanganti. 


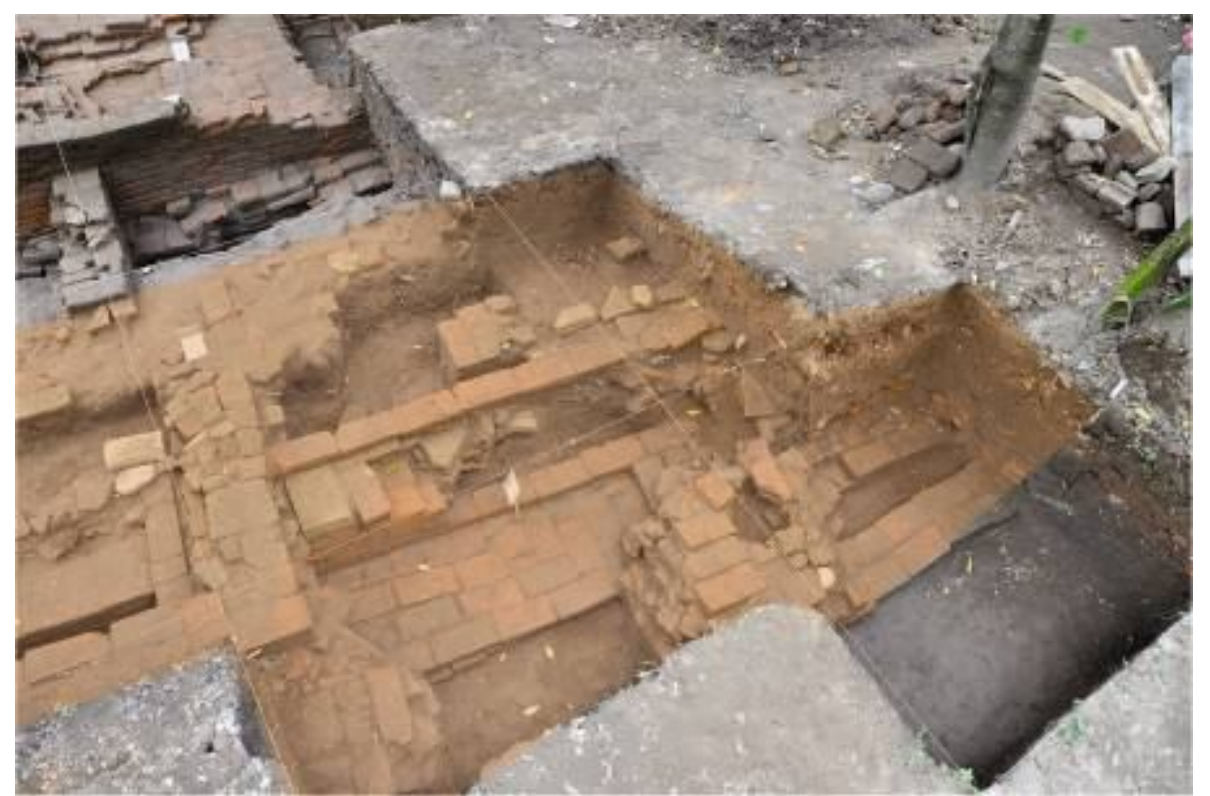

Foto 6. Detail struktur bata pada bangunan II

(Dok. Tim Penelitian Tahun 2013)

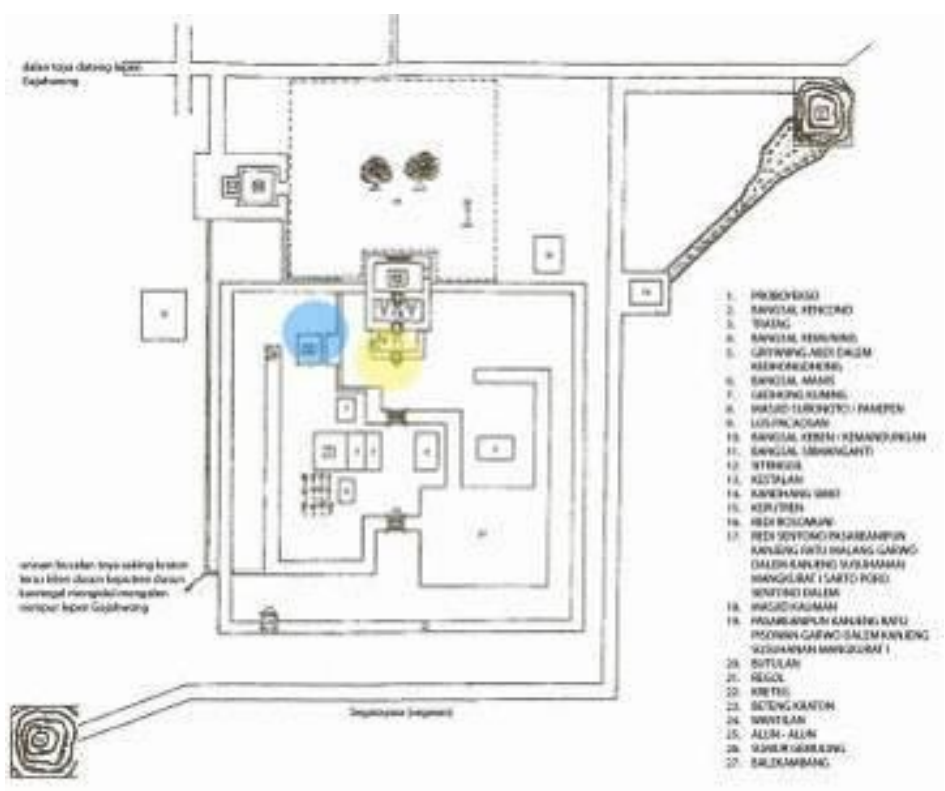

Gambar 2. Interpretasi lokasi bangunan II (lingkaran kuning)

(Sumber: Sketsa Kraton Pleret yang berasal dari perpustakaan Kraton Yogyakarta)

\section{INTEGRASI PETA KUNA PLERET DENGAN HASIL EKSKAVASI}

Peta kuno juga dimanfaatkan sebagai proses penelusuran sejarah dan rekonstruksi Kraton Pleret.Integrasi peta kuna dan hasil ekskavasi diyakini dapat mengetahui keberadaan lokasi keberadaan Kedaton Pleret. Hal ini didukung juga dengan pendekatan Geographic Information System (GIS). GIS atau Sistem Informasi Geografis (SIG) merupakan suatu sistem berbasis komputer yang digunakan untuk menyimpan dan memanipulasi informasiinformasi geografis (Prahasta 2009, 1). Dalam prosesnya, data informasi geografis yang diperoleh diolah dengan menggunakan perangkat lunak (software), yaitu: Arc View 3.2 dan Arc GIS 10. Analisis yang digunakan dalam pemrosesan data spasial yang telah dipereoleh adalah dengan menggunakan analisis overlay. Analisis overlay (tumpang-susun) merupakan penggabungan dua tema atau lebih dari 
areal yang sama untuk membentuk peta baru.

Proses overlay dimulai dari penyiapan Peta Rupa Bumi Indonesia (RBI) analog yang telah discan dan diregistrasi sehingga memiliki sistem koordinat. Peta kuno yang digunakan yaitu Peta Kuno Rouffaer- anpa tahun karena benteng berbentuk jajaran genjang dan sesuai dengan fakta di lapangan hasil ekskavasi tahun 2009, 2010, dan 2011. Pada peta RBI lembar Timoho terdapat gejala alam dengan landuse (tata guna lahan) kebun/perkebunan yang membentuk pola jajaran genjang. Gejala alam yang teridentifikasi pada peta RBI yaitu pada sisi barat yang terlihat dengan jelas dan sisi timur yang kurang begitu jelas/samar-samar. Sedangkan pada sisi utara dan selatan gejala alam telah berubah menjadi landuse pemukiman sehingga batas utara dan selatan masih perlu diklarifikasi lagi.

Peta kuno Rouffaer, tanpa tahun yang ditumpang-susunkan di atas peta RBI dengan mengacu pada batas-batas benteng Kraton Pleret terhadap gejala alam yang dapat diamati pada peta RBI. Hasil tumpang-susun tersebut didukung dengann kegiatan ploting dengan GPS pada beberapa situs di wilayah KCB Pleret yang masih memiliki korelasi dengan Kraton Pleret. Berikut ini merupakan hasil analisis overlay yang telah

dilakukan:

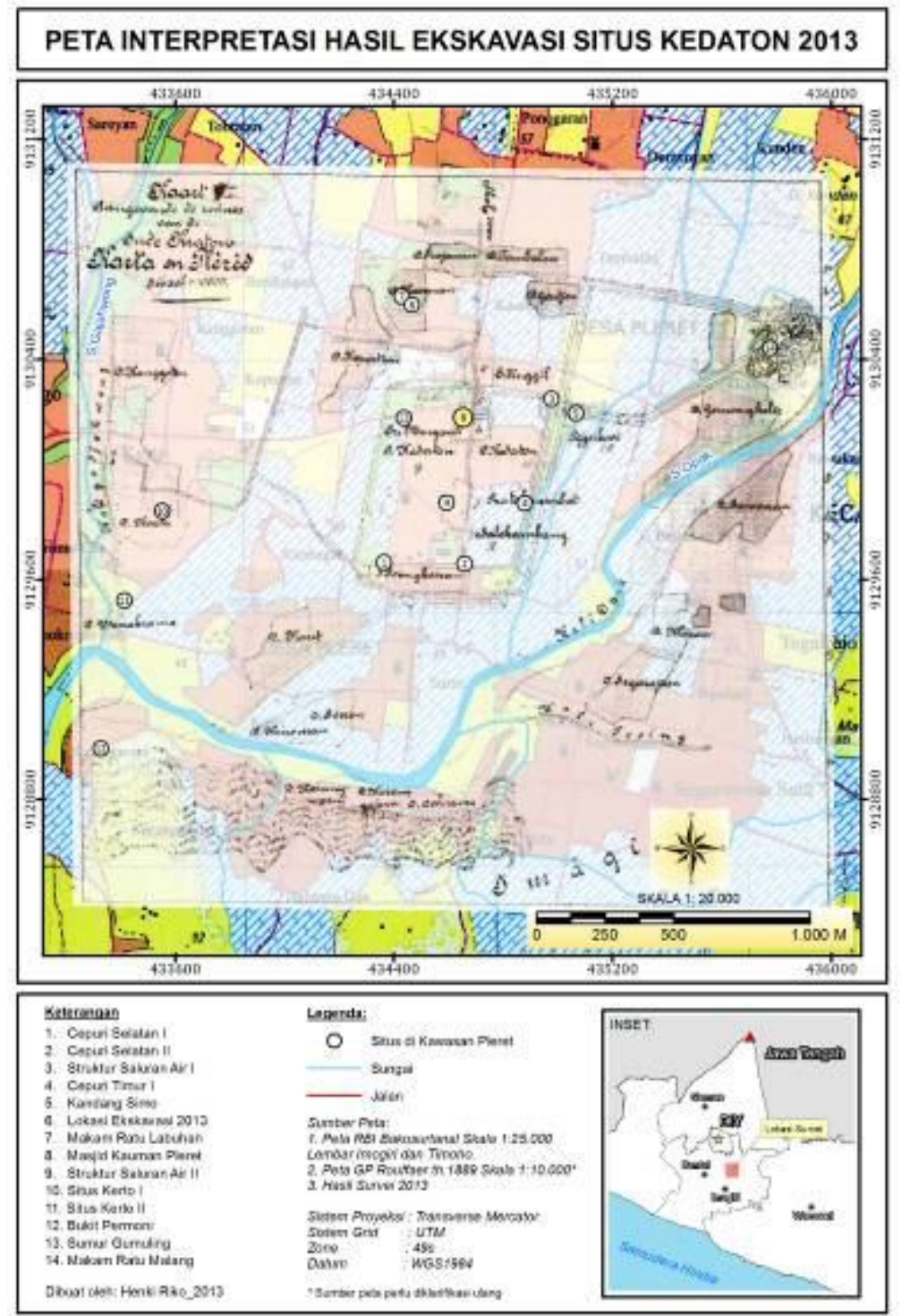

Peta 4. Peta hasil integrasi antara Peta RBI dengan Peta Kuno Rouffaer, tanpa tahun. Sumber: Laporan Ekskavasi Situs Kedaton Tahap VI 
Hasil analisis overlay diatas memberikan informasi mengenai lokasi ekskavasi tahun 2013 yaitu berada pada Bangsal Keben. Temuan yang berupa struktur bata selebar 2,6 meter dengan ketebalan 20 lapis berorientasi utara timur merupakan bagian dari Cepuri Bangsal Keben. Hasil overlay diperkuat dengan keletakan situs-situs di wilayah KCB Pleret, seperti masjid kauman, makam labuhan, cepuri selatan dan cepuri timur tepat berada di lokasi yang tertera pada peta kuno serta situs lain seperti situs Gunung Kelir, Situs Kerta, Bukit Permoni, Situs Kerto, dan Kandang Simo masih dapat dirunut.

\section{PENUTUP}

Hasil kegiatan ekskavasi Situs Kedaton tahun 2013 dari hasil pembukaan 28 kotak ekskavasi diperoleh informasi yaitu :

a. Lokasi penelitian Situs kedaton Tahun 2013 merupakan lokasi yang mempunyai potensi tinggalan arkeologi yang cukup tinggi berupa data artefaktual maupun monumental yang berkaitan dengan Kraton Pleret.

b. Berdasarkan karakter data arkeologi diketahui bahwa Situs Kedaton merupakan situs permukiman yang mempunyai sistem pranata sosial mapan dan kompleks. Berdasarkan bentuk data artefaktual yang dijumpai sebagian besar berbentuk wadah berbahan gerabah dan keramik berkualitas bagus. Temuan data monumental di Situs Kedaton semakin memperkuat interpretasi karakter Situs Kedaton sebagai lokasi Kraton Pleret, yaitu bagian dari Cepuri Keben, Bangsal Suronatan, dan Bangsal Srimanganti.

c. Integrasi data hasil ekskavasi dan peta kuna mengenai Kraton Pleret mempunyai korelasi dan memperkuat interpretasi mengenai bentuk dan karakter data artefaktual dan monumental (arsitektural) yang dijumpai di Situs Kedaton.
UCAPAN TERIMAKASIH

Terima kasih ditujukan kepada Rully Andriadi, S.S. (Dinas Kebudayaan D.I Yogyakarta) yang telah memberikan kesempatan kepada penulis untuk mempublikasikan hasil penelitian Situs Kedaton Pleret tahun 2013. 


\section{DAFTAR PUSTAKA}

Adrisijanti, Inajati. 2000. Arkeologi Perkotaan Mataram Islam. Yogyakarta: Jendela.

Alifah dan Hery Priswanto. 2012. Benteng Kraton Pleret: Data Historis dan Data Arkeologi dalam Berkala Arkeologi Vol. 32 No. 2 - November 2012. Yogyakarta: Balai Arkeologi Yogyakarta.

Dwiyanto, Joko. 2009. Ensiklopedi Kraton Yogyakarta. Yogyakarta: Dinas Kebudayaan Provinsi DI Yogyakarta.

Prahasta, Eddy. 2009. Sistem Informasi Geografis: Tutorial Arc View. Bandung: Informatika.

Priswanto, Hery \& Alifah, 2011. "Optimalisasi Potensi dan Tata Kelola Kawasan Cagar Budaya Pleret, dalam Arkeologi dan Publik. Yogyakarta: Balai Arkeologi Yogyakarta.

Tim Penelitian, 2008. Laporan Ekskavasi Situs Purbakala Di Kawasan Cagar Budaya Pleret Tahun 2008 Situs Kedaton (Tahap I).Yogyakarta: Dinas Kebudayaan Provinsi Daerah Istimewa Yogyakarta.

-, 2009. Laporan Ekskavasi Situs Purbakala Di Kawasan Cagar Budaya Pleret Tahun 2009 Situs Kedaton (Tahap II).Yogyakarta: Dinas Kebudayaan Provinsi Daerah Istimewa Yogyakarta

2010. Laporan Ekskavasi Situs Purbakala Di Kawasan Cagar Budaya Pleret Tahun 2010 Situs Kedaton (Tahap III). Yogyakarta: Dinas Kebudayaan Provinsi Daerah Istimewa Yogyakarta.

-, 2011. Laporan Ekskavasi Situs Purbakala Di Kawasan Cagar Budaya Pleret Tahun 2011 Situs Kedaton (Tahap IV). Yogyakarta: Dinas Kebudayaan Provinsi Daerah Istimewa Yogyakarta.

, 2012. Laporan Ekskavasi Situs Purbakala Di Kawasan Cagar Budaya Pleret Tahun 2012 Situs Kedaton (TahapV). Yogyakarta: Dinas Kebudayaan Provinsi Daerah Istimewa Yogyakarta.

, 2013. Laporan Ekskavasi Situs Purbakala Di Kawasan Cagar Budaya Pleret Tahun 2013 Situs Kedaton (TahapVI). Yogyakarta: Dinas Kebudayaan Daerah Istimewa Yogyakarta. 